\title{
TU/e EN⿴HONE

\section{Stable and scalable smart window based on polymer stabilized liquid crystals}

\section{Citation for published version (APA):}

Hu, X., Zhang, X., Yang, W., Jiang, X. F., Jiang, X., de Haan, L. T., Yuan, D., Zhao, W., Zheng, N., Jin, M., Shui, L., Schenning, A. P. H. J., \& Zhou, G. (2020). Stable and scalable smart window based on polymer stabilized liquid crystals. Journal of Applied Polymer Science, 137(30), [48917]. https://doi.org/10.1002/app.48917

\section{Document license:}

TAVERNE

DOI:

10.1002/app.48917

Document status and date:

Published: 10/08/2020

\section{Document Version:}

Publisher's PDF, also known as Version of Record (includes final page, issue and volume numbers)

\section{Please check the document version of this publication:}

- A submitted manuscript is the version of the article upon submission and before peer-review. There can be important differences between the submitted version and the official published version of record. People interested in the research are advised to contact the author for the final version of the publication, or visit the $\mathrm{DOI}$ to the publisher's website.

- The final author version and the galley proof are versions of the publication after peer review.

- The final published version features the final layout of the paper including the volume, issue and page numbers.

Link to publication

\section{General rights}

Copyright and moral rights for the publications made accessible in the public portal are retained by the authors and/or other copyright owners and it is a condition of accessing publications that users recognise and abide by the legal requirements associated with these rights.

- Users may download and print one copy of any publication from the public portal for the purpose of private study or research.

- You may not further distribute the material or use it for any profit-making activity or commercial gain

- You may freely distribute the URL identifying the publication in the public portal.

If the publication is distributed under the terms of Article 25fa of the Dutch Copyright Act, indicated by the "Taverne" license above, please follow below link for the End User Agreement:

www.tue.nl/taverne

Take down policy

If you believe that this document breaches copyright please contact us at:

openaccess@tue.nl

providing details and we will investigate your claim. 


\title{
Applied Polymer
}

\section{Stable and scalable smart window based on polymer stabilized liquid crystals}

\author{
Xiaowen Hu ${ }^{1},{ }^{1}$ Xinmin Zhang, ${ }^{1}$ Wenmin Yang, ${ }^{1}$ Xiao-Fang Jiang, ${ }^{2}$ Xinshuai Jiang, ${ }^{2}$ \\ Laurens T. de Haan, ${ }^{1}$ Dong Yuan, ${ }^{1}$ Wei Zhao, ${ }^{1}$ Nan Zheng, ${ }^{3}$ Mingliang Jin, ${ }^{2}$ Lingling Shui, ${ }^{2}$ \\ Albertus P. H. J. Schenning, ${ }^{4}$ Guofu Zhou ${ }^{1,5}$ \\ ${ }^{1}$ SCNU-TUE Joint Lab of Device Integrated Responsive Materials (DIRM) and National Center for International Research on Green \\ Optoelectronics, South China Academy of Advanced Optoelectronics, South China Normal University, Guangzhou 510006, People's \\ Republic of China \\ ${ }^{2}$ Guangdong Provincial Key Laboratory of Optical Information Materials and Technology \& Institute of Electronic Paper Displays, \\ South China Normal University, Guangzhou 510006, People's Republic of China \\ ${ }^{3}$ State Key Laboratory of Luminescent Materials and Devices, South China University of Technology, Guangzhou 510640, People's \\ Republic of China \\ ${ }^{4}$ Chemical Engineering and Chemistry, Functional Organic Materials and Devices, Eindhoven University of Technology, 5600 MB, \\ Eindhoven, The Netherlands \\ ${ }^{5}$ Shenzhen Guohua Optoelectronics Technology Co., Ltd., Shenzhen 518110, People's Republic of China \\ Correspondence to: X. Hu (E-mail: xwhu@m.scnu.edu.cn); X.-F. Jiang (E-mail: jiangxf@scnu.edu.cn)
}

ABSTRACT: A stable and scalable polymer-stabilized liquid crystal window which electrically switches from transparent to opaque has been fabricated. Scanning electron microscope measurement shows that higher polymer concentration will induce denser polymer network in polymer stabilized liquid crystal system and then stronger anchoring force between polymer network and liquid crystal molecules, which resulting in larger operating voltage. The cell with larger cell gap has a lower saturated transmittance in the voltage-on state, which attributed to a larger number of scattering domains in thick cell. The optimized cell exhibits a highly transparent voltageoff state (3.5\% haze) and a voltage-on scattering state ( $98 \%$ haze) with the threshold voltage of around $20 \mathrm{~V}$. The durability test shows that the optical device switches at least 100,000 times without degradation of optical contrast and shows a high temperature tolerance. Meanwhile, a $40 \times 50 \mathrm{~cm}^{2}$ window has been developed in an industrial production line showing the same optical properties. Our results demonstrate the fabrication of smart windows with a highly transparent rest state and high optical contrast on a commercial mass production scale, making them attractive for applications in buildings, automobiles, and switchable sunglasses for light management and potentially energy saving. (o) 2020 Wiley Periodicals, Inc. J. Appl. Polym. Sci. 2020, 137, 48917.

KEYWORDS: applications; liquid crystals; optical properties

Received 31 July 2019; accepted 24 November 2019

DOI: $10.1002 / a p p .48917$

\section{INTRODUCTION}

Smart windows that enable electronic control of visible and infrared light have attracted extensive attention in both academia and industry due to their potential for architectural aesthetics, occupant comfort, and energy efficiency. ${ }^{1,2}$ Currently, various methods are known to fabricate such windows. ${ }^{3,4}$ However, taking into account the specific properties of window glass in buildings or vehicles, one strict rule has to be considered: switching from an unpowered, transparent rest state to opaque on application of an external stimulus has to be possible. Currently, two different technologies are commonly used for this purpose: electrochromic ${ }^{2,3,5}$ and polymer/liquid crystal systems. ${ }^{6,7}$

Polymer/liquid crystal systems have particular advantages such as fast switching, easy regulation, and low-cost preparation. ${ }^{7-9}$ On the basis of polymer concentration, two types of polymer/liquid crystal systems have been developed in the past. One type is known as polymer dispersed liquid crystals (PDLCs). ${ }^{10}$ In these windows, LCs are dispersed as droplets in a continuous polymer matrix. Due to the dense polymer network, the anchoring force 
inhibits the reorientation of the LC directors, which results in a high driving voltage for switching. ${ }^{11}$ Besides, reverse-mode (rest state is transparent) PDLC through coating an alignment layer and refractive index matching has also been demonstrated. ${ }^{12}$ However, the transparency at power off state still needs further improvement. The other form of a polymer/liquid crystal system is called polymer stabilized liquid crystals (PSLC). ${ }^{13-15}$ In this system, the LC materials represent the continuous matrix, while a small amount of polymer network (typically a few percent in weight) is dissolved in the anisotropic fluid. ${ }^{13,14}$ Due to the smaller polymer concentration, PSLC-based smart windows exhibit a highly transparent state and lower driving voltage compared to PDLC films. However, the relatively weak haze of PSLC in the scattering state, that is, $40-50 \%$, significantly limits its applications. ${ }^{16}$ Meng et al. recently reported a type of reversemode PSLC window by introducing an inhomogeneous alignment surface. ${ }^{9}$ The haze of this window in the voltage-on state can be enhanced to $64 \%$, which is still lower than PDLC-based windows. Jeon et al. found that low-temperature curing can increase the haze in the scattering state, but this required a high operation voltage $(58 \mathrm{~V})$ to maintain the scattering. ${ }^{17}$ In our previous work, doping a dichroic dye can help to increase off-on state contrast of PSLC devices, ${ }^{18}$ while it will bring on a potentially stability problem due to degradation of the dichroic dye under ultraviolet (UV) irradiation. Besides these examples, the scalability and stability of PSLC-based devices has been rarely investigated. ${ }^{15-19}$

In this work, we fabricated reverse-mode PSLC smart windows with a homeotropic polyimide (PI) alignment layer. Usually, the azimuthal LC anchoring force is determined by mechanical buffing on the PI alignment layer. The homeotropic PI is used to induce $90^{\circ}$ pretilt angle for vertical alignment, which guarantee a great homeotropic off state for PSLC cell. By optimizing the concentration of the polymer and the cell gap, we obtained an optimized PSLC smart window with an off-state haze of 3.5\% and on state haze of $98 \%$. Reliability tests show that the PSLC smart windows exhibit a superior switching reliability and high temperature stability. Furthermore, we have taken a first step toward scaling up the windows by developing a generation 2.5 (G 2.5, size $40 \times 50 \mathrm{~cm}^{2}$ ) industrial production line, and a G2.5 prototype of PSLC smart device with excellent electro-optical properties is demonstrated.

\section{RESULTS AND DISCUSSION}

The operating principle behind the reverse-mode PSLC-based smart window involves the use of an electric field to switch between a transparent rest state and a scattering on state. Figure 1(a) shows the schematics of a reverse-mode PSLC device without and with an applied AC voltage. In the voltage-off state, the LC director is homeotropically aligned due the presence of the vertical PI alignment layer. This alignment is further stabilized by the polymer network. In this voltage-off state, the incident light is transmitted, and the cell is transparent. In the voltage-on state, the negative dielectric anisotropy LC reorients, deviating from the vertically alignment. LC molecules in the vicinity of the polymer network keep their original orientations, while the bulk LC molecules reorient to various azimuthal and polar angles, resulting in randomly aligned polydomains. ${ }^{9}$ As a consequence, the incident light is strongly scattered by the different refractive indices, causing the cell to become opaque.

For the fabrication of the PSLC devices, the LC mixture consisted of both reactive (polymerizable) and nonreactive (nonpolymerizable) mesogens mixed with a photo-initiator. The nematic nonreactive LC mixture HNG30400 with negative dielectric anisotropy was chosen. The homeotropic aligned LC director will reorient upon application of an AC electric field. Diacrylate monomer RM82 was chosen which can be polymerized under UV irradiation. Scheme 1 shows the molecular structures of the chemicals used for the fabrication of PSLC devices. HNG30400 is a mixed liquid crystal, whose structures are not provided by supplier. We prepared LC mixtures by mixing 96.9 wt \% of HNG30400 with 3 wt \% of the diacrylate monomer RM82 and 0.1 wt \% of the photo-initiator Irgacure 651. Cells with a size of $3 \times 3 \mathrm{~cm}^{2}$ were constructed from ITO-covered glass coated with a homeotropic PI layer and separated by uniformly dispersed glass spheres with a diameter of $5 \mu \mathrm{m}$ to control the cell gap. The cells were filled with the LC mixture by capillary action and photopolymerized by irradiating with UV light. In the rest state, the PSLC cells were clear, with a transmittance of $96.8 \%$ at a wavelength of $550 \mathrm{~nm}$, and a haze of 3.5\% [Figure 1(b,c)]. A background pattern placed behind the cell was clearly visible, confirming a transparent state [Figure 1(b)]. When we applied $40 \mathrm{~V}$, the cell switched to a scattering state and the background pattern was obscured. The transmittance was $10.1 \%$, with a haze of $91 \%$ [Figure $1(\mathrm{c})$ ]. When the transmittance (haze) was plotted as function of the applied AC voltage, it became clear that $40 \mathrm{~V}$ was required to switch between a high transparent and scattering state [Figure 1(c)]. Polarization optical microscopy confirms a dark state (homeotropic state) at $0 \mathrm{~V}$ between cross polarizer while a clear state (scattering state) is observed at $40 \mathrm{~V}$ [Figure 1(d)].

To investigate the effect of the polymer concentration on the electro-optical properties of the PSLC cells, cells containing different concentrations of diacrylate LC monomer were prepared.
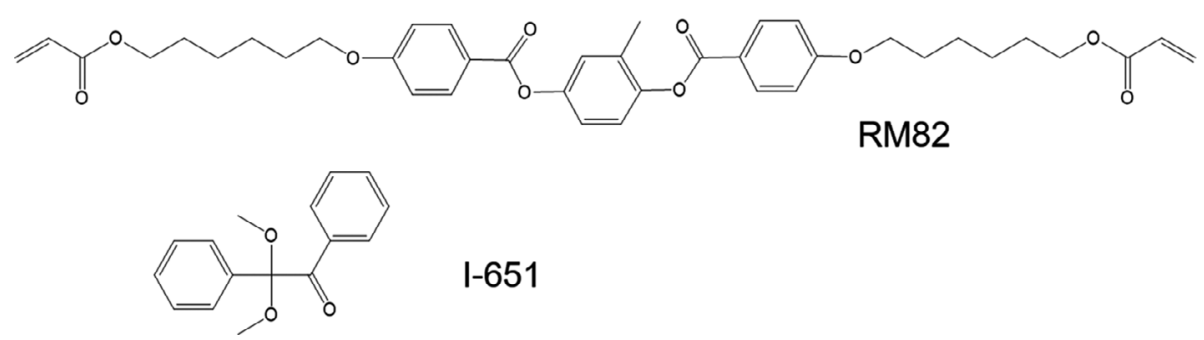

I-651

Scheme 1. Molecular structure of diacrylate monomer RM82 and photoinitiator Irgacure 651 (I-651). 
(a)

(b)

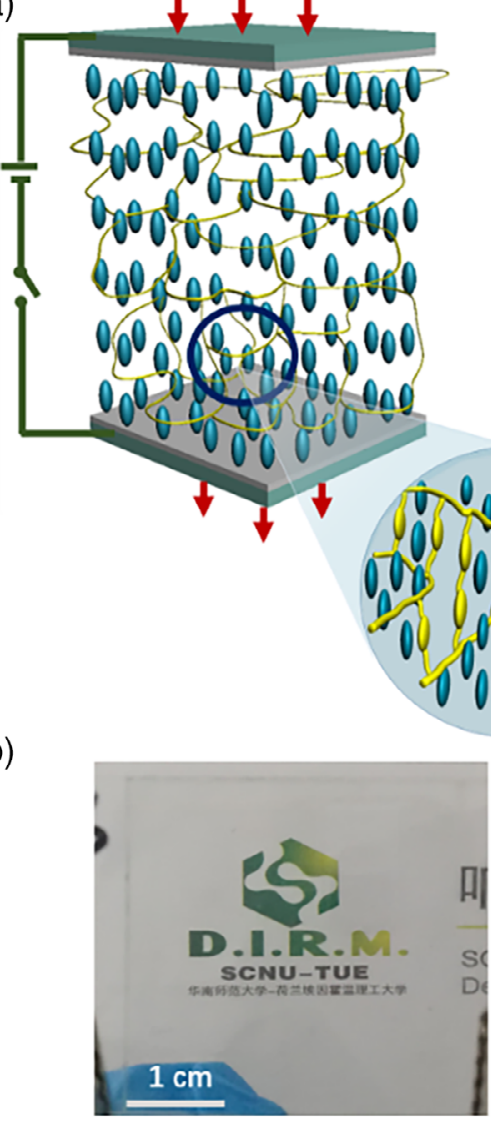

(c)

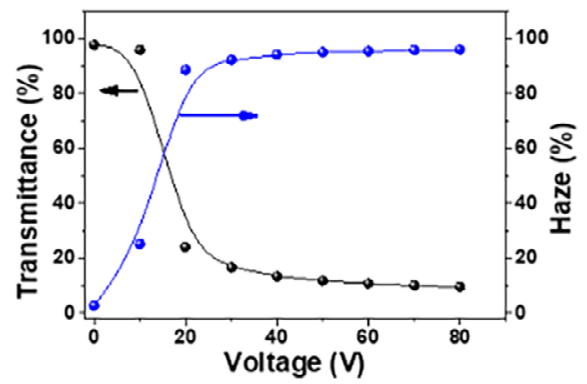

Polymer network

0 Liquid crystal

$\downarrow$ Incident light

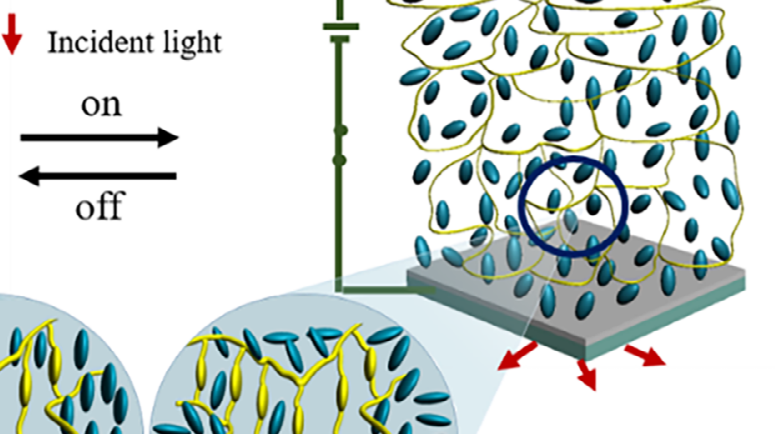

10
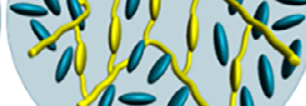

$\perp \perp 1$
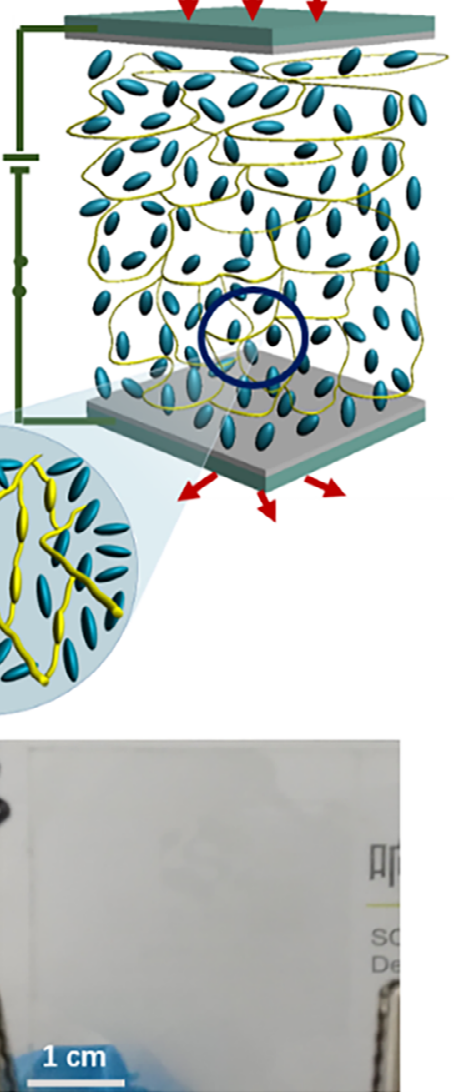

(d)

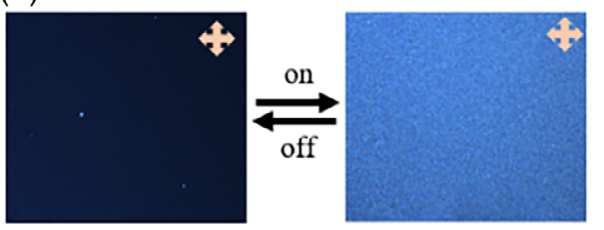

Figure 1. (a) Schematic illustration of the PSLC-based system in the voltage-off state and voltage-on state. (b) Photograph of the PSLC cell in the off state and on state $(40 \mathrm{~V})\left(\right.$ size $\left.3 \times 3 \mathrm{~cm}^{2}\right)$. (c) Transmittance-voltage (T-V) curves and haze characteristic of the PSLC cell. (d) POM images of the cell in the off state $(0 \mathrm{~V})$ and on state. [Color figure can be viewed at wileyonlinelibrary.com]

The transmittance spectra were measured while increasing the AC voltage. The transmittance-voltage $(\mathrm{T}-\mathrm{V})$ curves of the devices are shown in Figure 2(a). It is apparent that the maximum transmittance of the cells at zero voltage was independent of the polymer concentration. For a typical PSLC system, a few amounts of polymer network are dissolved in liquid crystals. The basic idea of introducing a polymer network into the LC matrix is a transfer of the orientational order of the LC mesophase to the polymer network during polymerization, and thus stabilization of the original texture. For the cell without polymer, the LC molecules would rotate freely under applied voltage, from a homeotropic monodomain to a planar monodomain, which resulted in an almost unchanged transmittance. When $3 \%$ polymer was present, the transmittance of the cell decreased upon increasing the voltage because of multidomain scattering. This light scattering is due to the presence of the network, keeping LC molecules in the vicinity of the polymer strands in their original orientation, while the bulk material reorients under field application. As the polymer concentration is increased from 3 to $9 \%$, a larger threshold voltage $\left(V_{\text {th }}\right)$ was required to switch the cell to the scattering state, along with a higher saturation voltage $\left(V_{\text {sat }}\right)$ [Figure 2(b)]. Here, the $V_{\text {th }}$ and $V_{\text {sat }}$ are defined as the voltages at which 90 and $10 \%$ of the maximum transmittance is measured in the voltage ramp-down transmittance curve, respectively. ${ }^{20}$

The increase of $V_{\text {th }}$ and $V_{\text {sat }}$ might be due to the increasing interface area between LC and polymer, giving rise to an enhanced anchoring force. ${ }^{21,22}$ When the polymer concentration was 

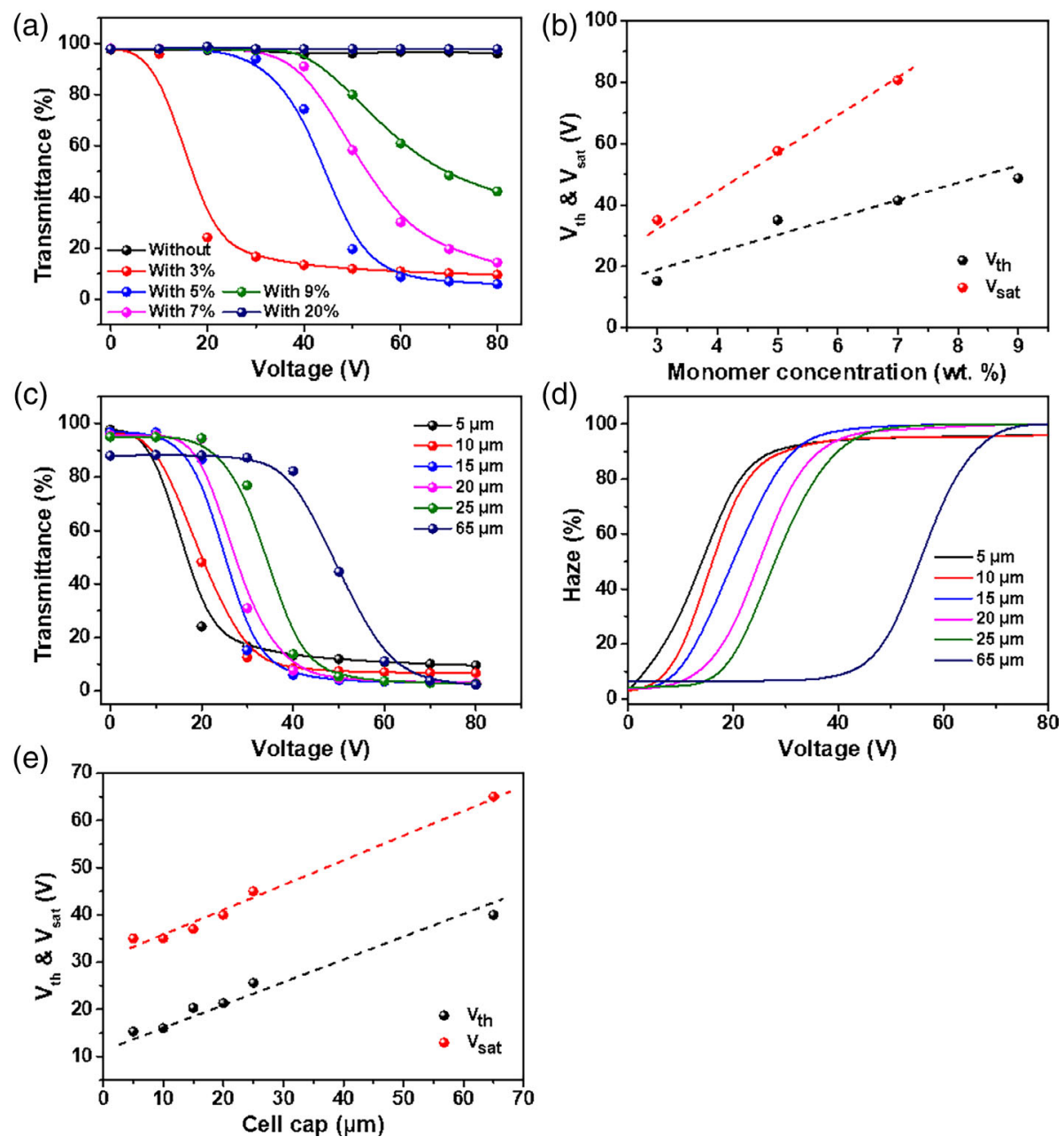

Figure 2. (a) Transmittance-voltage (T-V) curves of PSLC cells prepared without monomer or with different monomer concentrations. (b) Threshold voltage $\left(V_{\text {th }}\right)$ and saturation voltage $\left(V_{\text {sat }}\right)$ of the PSLC cells with different monomer concentrations. (c) T-V curves of PSLC cells with different cell gaps. (d) Haze-voltage (H-V) curves of PSLC cells with different cell gap. (e) $V_{\text {th }}$ and $V_{\text {sat }}$ of PSLC cells with different cell gaps. [Color figure can be viewed at wileyonlinelibrary.com]
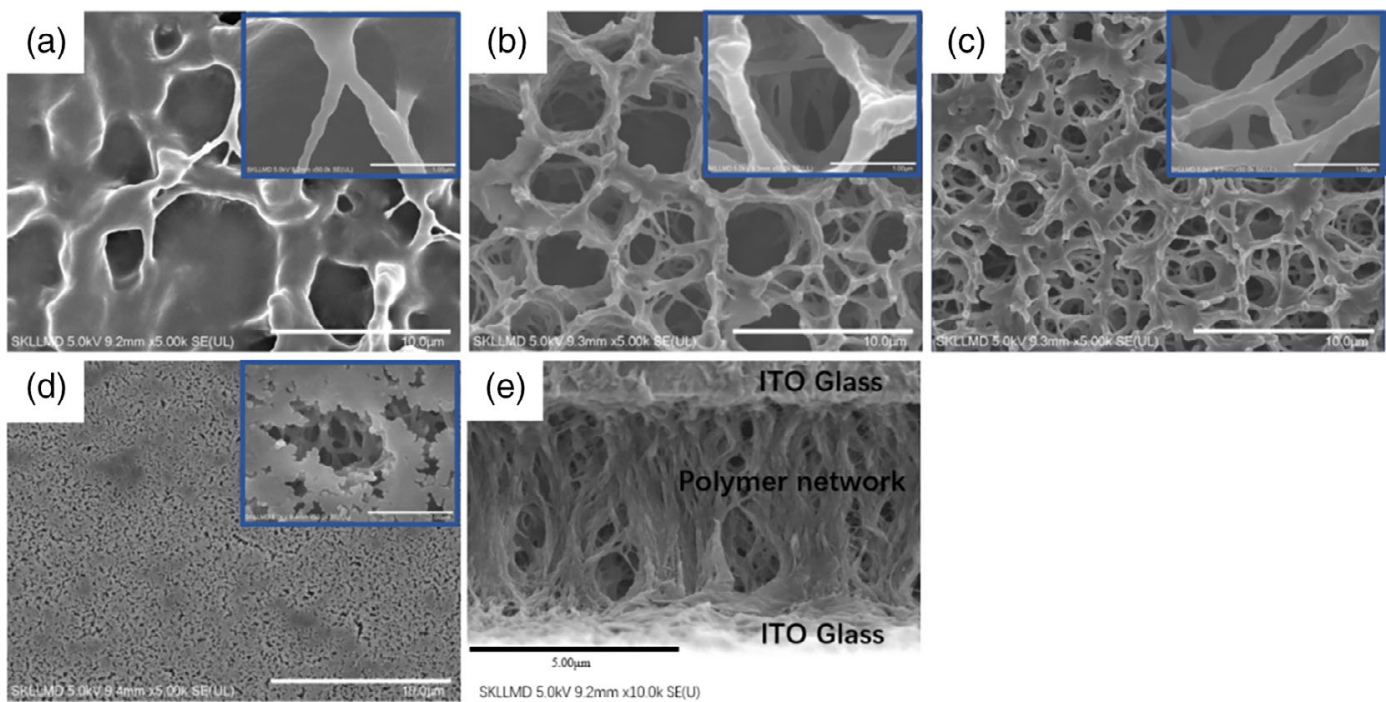

Figure 3. Top view SEM images of polymer network from different monomer concentrations (the scale bar is $10 \mu \mathrm{m}$ ). Zoom-in images with a scale bar of $1 \mu \mathrm{m}$ are showed in the top right corner of each picture. (a) 3, (b) 7, (c) 9, and (d) $20 \%$ monomer concentration. (e) Sectional view SEM image of polymer network from $7 \%$ monomer concentration. [Color figure can be viewed at wileyonlinelibrary.com] 

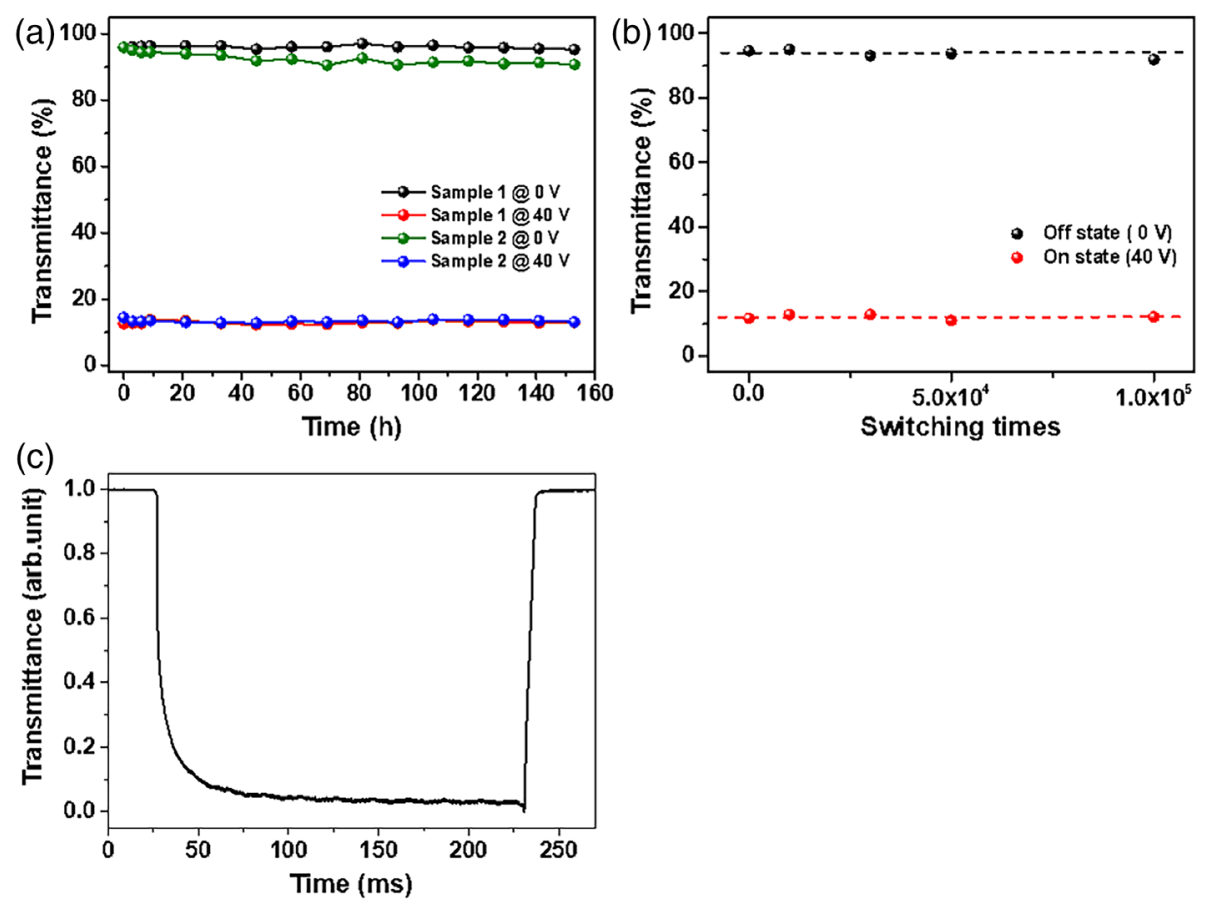

Figure 4. (a) Transmittance versus time for Sample 1 (kept in room temperature) and Sample 2 (kept in an oven at $80^{\circ} \mathrm{C}$ ). (b) Transmittance of a PSLC cell in the off state and on state as a function of switching times. (c) Response time of PSLC cells. [Color figure can be viewed at wileyonlinelibrary.com]

(a)

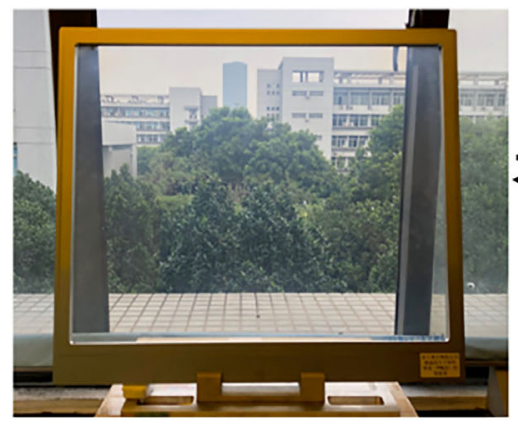

(b)

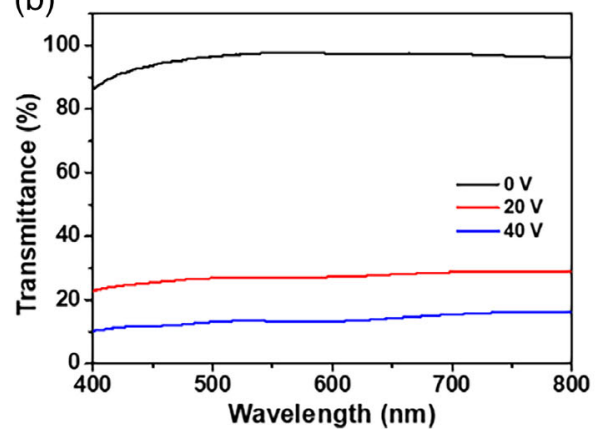

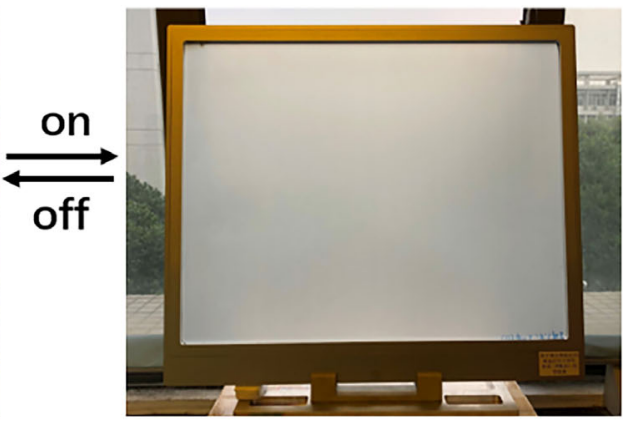

Figure 5. (a) Prototype of a G2.5 size $\left(40 \times 50 \mathrm{~cm}^{2}\right)$ window in the off state $(0 \mathrm{~V})$ and on state $(40 \mathrm{~V})$. (b) Transmittance of G2.5 size window versus wavelength under applying different voltages. A video of this switching action may be found in the Supporting information. [Color figure can be viewed at wileyonlinelibrary.com]

further increased to $20 \%$, the polymer network anchoring force was too high, and the electro-optical response was lost. We investigated the morphology of the polymer network by using scanning electron microscope (SEM). The top-view images reveal a finely structured polymer networks with pores of a fairly uniform round shape [Figure $3(\mathrm{a}-\mathrm{d})$ ]. Increasing the concentration of the polymer from 3 to $20 \%$ resulted in a decrease in the size of the pores, indicating that the density of the polymer network had increased. The increase in density of the polymer network suggests that the total LC/polymer interfacial area was larger, 
resulting in a stronger anchoring force between polymer network and LC. ${ }^{22,23}$ This, in turn, resulted in the observed high threshold and saturation voltage. Sectional view image [Figure 3(e)] shows a continuous network which fills the whole cell, connecting both glass substrates, which is a characteristic property of network in PSLC system. ${ }^{14}$ From the above results, the PSLC cell that contains $3 \%$ polymer shows a high contrast and low operating voltage. Therefore, this cell was investigated further.

The dependence of the electro-optical properties on the cell gap was further investigated. The $\mathrm{T}-\mathrm{V}$ curves of the various cells are shown in Figure 2(c). The transmittance in the off state does not vary when the cell gap was less than $25 \mu \mathrm{m}$. It decreased when the cell gap was increased to $65 \mu \mathrm{m}$. For example, in the off state, the transmittance of a $25 \mu \mathrm{m}$ cell was $95 \%$ and that of a $65 \mu \mathrm{m}$ cell was $87 \%$, which might be attributed to the presence of a larger number of scattering domains in the $65 \mu \mathrm{m}$ cell. This also explains why the cells with a larger cell gap have a lower saturated transmittance in the voltageon state, which corresponds to the haze performance of cells, as is presented in Figure 2(d). The operating voltage of the PSLC devices with different cell thickness was found to be almost proportional to the cell thickness [Figure 2(e)]. For PSLC system, the polymer network in the liquid crystal layer is aligned in the homeotropic direction, because of the monomer reactions in the liquid crystal phase. The liquid crystal molecules are then aligned by the polymer network and the operating voltages of PSLC devices are determined by the bulk effect of the polymer network, not the surface effect of the alignment layer. Based on these results, it was concluded that a $15 \mu \mathrm{m}$ spaced cell has the best characteristics with respect to the amount of material used and the voltage-off transparent and voltage-on scattering state.

The storage reliability of PSLC cells was tested at high temperatures. One cell (Sample 2) was kept in an environment of $80^{\circ} \mathrm{C}$ and another cell (Sample 1) at room temperature as a control for a duration of $150 \mathrm{~h}$. In the off state, the transmittance of Sample 2 fluctuates less than $5 \%$ in such a harsh storage environment compared to Sample 1 [Figure 4(a)]. The on-state transmittance is the same as for the control device. The result reveals that our cells have an excellent stability. For the switching endurance test, a cell was subjected to an applied voltage of $40 \mathrm{~V}$ and switched on and off every $3 \mathrm{~s}$. The fatigue of the cell is illustrated by plotting the transmittance as a function of time, as shown in Figure 4(b). The unchanged transmittance of the smart window in the off state and on state indicates that this cell is stable over the course of switching 100,000 times. The native response time for a PSLC sample is shown in a plot of transmittance as a function of time, as shown in Figure 4(c). The transmittance drops down to $10 \%$ of its maximum value upon applying voltage with a switch-on time of approximately $21 \mathrm{~ms}$. After the voltage is removed, the transmittance returns to the original value in $6 \mathrm{~ms}$. Although the response time is longer compared with that of LC materials system employed in display devices, the switching time reported here may be sufficiently short to use these PSLC devices for the applications of smart windows.

To show the industrial relevance of our findings, a first step toward upscaling our cell was undertaken. By using a generation 2.5 (G 2.5, size $40 \times 50 \mathrm{~cm}^{2}$ ) industrial production line (see Figure $\mathrm{S} 1$, Supporting information) and using the optimized device parameters
(3\% polymer, $15 \mu \mathrm{m}$ cell gap), a G2.5 prototype smart window was fabricated. The transparency of this large size window in the off and on state is shown in Figure 5(a). In the off state, the window was transparent and the outdoor environment was clearly visible. In the on state $(40 \mathrm{~V})$, the window turned opaque, and the outdoor environment became obscured. Figure 5 (b) shows the transmission spectrum of the large size window under applying various voltages. It shows a high transmittance at 0 and $10 \mathrm{~V}$; more than $95 \%$ from 500 to $800 \mathrm{~nm}$. At $20 \mathrm{~V}$, the transmittance started to drop. It suggests that the threshold voltage of the window is around $20 \mathrm{~V}$, which is consistent with the threshold voltage of the PSLC cells with the same cell gap [Figure 2(e)]. When $40 \mathrm{~V}$ was applied, the transmittance decreased dramatically, to less than $10 \%$ in the whole visible region, proving a strong opaque state. The characteristics of the $\mathrm{T}-\mathrm{V}$ of the large size window are consistent with that of the PSLC cells. These results show that it is feasible to make large sized PSLC based smart windows on an industrially relevant scale.

\section{CONCLUSIONS}

A stable and scalable polymer-stabilized liquid crystal window which electrically switches from transparent to opaque has been fabricated. We have demonstrated that both the polymer concentration and cell gap play an important role in the electricaloptical properties of the windows. The optimized window exhibits a large haze ( $98 \%$ haze) in the voltage-on scattering state, while it maintained a clear state (3.5\% haze) in the voltage-off state. The default clear state is particularly useful for window applications since no electrical power is needed to maintain a window view. The device switches at least 100,000 times without degradation of the optical contrast and shows a high temperature tolerance. Meanwhile, a $40 \times 50 \mathrm{~cm}^{2}$ window has been developed in a generation 2.5 (G2.5) industrial production line. Our results reveal that PSLC smart windows with excellent optical characters can potentially be produced on an industrial scale. This makes these windows appealing as switching privacy glass in buildings and automobiles, and architectural aesthetics aspects.

\section{EXPERIMENTAL}

The PSLC mixtures were made by mixing diacrylate monomer RM82 (purchased from HCCH), photoinitiator Irgacure 651 (purchased from HEOWNS), and a liquid crystal with a negative dielectric constant HNG30400 $(\Delta \varepsilon=-8.3, \Delta n=0.149$, purchased from $\mathrm{HCCH})$. Cells were constructed from ITO-covered glass plates which were separated by uniformly dispersed glass spheres with a diameter of $5-65 \mu \mathrm{m}$ to control cell spacing and glued together using Norland optical adhesive (NOA65), with a slight offset to provide access to the ITO electrode for the electrical contact. Homeotropic alignment was achieved by applying a homeotropic PI to the slides prior to cell construction. Capillary action was used to fill the $3 \times 3 \mathrm{~cm}^{2}$ cells. These filled cells were then exposed to UV light with an intensity of $27 \mathrm{mw} / \mathrm{cm}^{2}$ for $3 \mathrm{~min}$ to induce UV polymerization. Vacuum filling was used to fill the $40 \times 50 \mathrm{~cm}^{2}$ cell. For the UV curing process, in pilot line, we have a customized UV curing machine with the active area of $500 \times 600 \mathrm{~mm}^{2}$, which was shown in Figure S1, Supporting Information. After filling the cell, we transferred the cell into the UV curing machine to polymerize with the same condition as did in the lab. 
The PSLC samples were studied using a polarizing optical microscope. The transmittance spectrum was measured using an Ocean Optics USB 4000 spectrometer. Haze was measured using a haze meter (CS-700). The morphology of the polymer network was characterized using an SEM (ZEISS Ultra 55). To prepare the samples for SEM, the backsides of the glass substrates were first cut to get symmetric scratches. Cells were made using these substrates and filled with the PSLC mixture. After polymerization, the cells were soaked in cyclohexane for 6 days to remove the liquid crystal. Finally, the cells were put into an oven to evaporate the solvent, and then frozen with liquid nitrogen to break them into a few pieces of small cells. The small cell was used to measure a cross-sectional view SEM after a thin layer of gold was applied to the section of the cell. For top view SEM measurements, the small cell was split, leaving only the polymer network on the glass substrate, and a thin layer of gold was applied to the polymer network.

\section{ACKNOWLEDGMENTS}

National Natural Science Foundation of China (51503070, 51711530651, 51603069, and 51561135014); Science and technology project of Guangdong Province (2018A050501012 and 2017B020240002); Program for Chang Jiang Scholars and Innovative Research Teams in Universities (IRT_17R40); Guangdong Innovative Research Team Program (2013C102); Guangdong Provincial Key Laboratory of Optical Information Materials and Technology (2017B030301007); and the 111 Project and Yunnan Expert Workstation (2017IC011).

\section{CONFLICT OF INTEREST}

The authors declare no potential conflict of interest.

\section{AUTHOR CONTRIBUTIONS}

X.H. prepared original draft; W.Y. and X.Z. performed the fabrication and characterization of lab sample; N.Z. performed SEM experiment; X.J. and D.Y. performed the fabrication of pilot line sample; L.d.H. and W.Z. performed the characterization of pilot line sample; M.J. and L.S. reviewed and edited the manuscript; and X-F.J., A.S., and G.Z. supervised the research.

\section{REFERENCES}

1. a) Barile, C. J.; Slotcavage, D. J.; Hou, J.; Strand, M. T.; Hernandez, T. S.; McGehee, M. D. Joule. 2017, 1, 133. b) Wang, X.; Zhang, G.; Ren, H. J. Display Technol. 2016, 12, 1565. c) Stangel, L. Startup raises $\$ 65 \mathrm{M}$ for its smart glasstinting technology, https://www.onenewspage.com.au/n/ Business/75e21qa3n/South-startup-raises-65M-for-its.htm, 2017; d) Wesoff, E. View has raised more than $\$ 500$ million for smart adaptive windows, https://www. greentechmedia.com/articles/read/View-Has-Raised-MoreThan-500-Million-for-Smart-Adaptive-Windows, 2015.

2. Azens, A.; Granqvist, C. J. Solid State Electrochem. 2003, 7,64 .

3. Granqvist, C.-G. Nat. Mater. 2006, 5, 89.

4. a) Abdulhalim, I.; Madhuri, P. L.; Diab, M.; Mokari, T. Opt. Express. 2019, 27, 17387. b) Kawai, K.; Sakamoto, M.;
Noda, K.; Sasaki, T.; Kawatsuki, N.; Ono, H. Appl. Optics. 2019, 58, 4234. c) Pappu, L. M.; Martin-Palma, R.; MartínAdrados, B.; Abdulhalim, I. J. Mol. Liq. 2019, 281, 108.

5. a) Ren, H.; Xu, S.; Wu, S.-T. Opt. Lett. 2012, 37, 1421. b) Vergaz, R.; Sanchez-Pena, J.-M.; Barrios, D.; Vazquez, C.; Contreras-Lallana, P. Solar Energy Mater. Solar Cells. 2008, 92, 1483.

6. a) Cupelli, D.; Nicoletta, F. P.; Manfredi, S.; Vivacqua, M.; Formoso, P.; De Filpo, G.; Chidichimo, G. Solar Energy Mater. Solar Cells. 2009, 93, 2008. b) Fuh, A. Y.-G.; Shin, Z. B.; Yang, C. H.; Wu, S.-T. Liq. Cryst. 2016, 43, 1784. c) Lu, H.; Chu, Y.; Jing, S.; Zhang, G.; Hu, J.; Lv, G.; Qiu, L. Liq. Cryst. 2017, 44, 437. d) Chu, Y.; Yin, Z.; Sha, J.; Xu, C.; Zhang, G.; Lv, G.; Qiu, L.; Lu, H. Liq. Cryst. 2017, 44, 688.

7. Meng, C.; Tseng, M. C.; Tang, S. T.; Zhao, C. X.; Yeung, S. Y.; Kwok, H. S. Liq. Cryst. 2019, 46, 484.

8. a) Macrelli, G. Solar Energy Mater. Solar Cells. 1995, 39, 123. c) Meng, C.; Chen, E.; Wang, L.; Tang, S.; Tseng, M.; Guo, J.; Ye, Y.; Yan, Q. F.; Kwok, H. Opt. Express. 2019, 27, 13098. d) Chen, C.-W.; Brigeman, A. N.; Ho, T.-J.; Khoo, I. C. Opt. Mater. Express. 2018, 8, 691.

9. Baetens, R.; Jelle, B. P.; Gustavsen, A. Solar Energy Mater. Solar Cells. 2010, 94, 87.

10. a) Sutherland, R.; Tondiglia, V.; Natarajan, L.; Bunning, T.; Adams, W. Appl. Phys. Lett. 1994, 64, 1074. b) Bunning, T. J.; Natarajan, L. V.; Tondiglia, V. P.; Sutherland, R. Ann. Rev. Mater. Sci. 2000, 30, 83. c) Coates, D. J. Mater. Chem. 1995, 5, 2063.

11. Lampert, C. M. IEEE Circ. Dev. Mag. 1992, 8, 19.

12. De Filpo, G.; Formoso, P.; Manfredi, S.; Mashin, A. I.; Nicoletta, F. P. Liq. Cryst. 2017, 44, 1607.

13. Hikmet, R. Mol. Cryst. Liq. Cryst. 1991, 198, 357. Hikmet, R. Liq. Cryst. 1991, 9, 405.

14. Hikmet, R.; Boots, H. Phys. Rev. E. 1995, 51, 5824.

15. a) Murai, H.; Gotoh, T.; Nakata, T.; Hasegawa, E. J. Appl. Phys. 1997, 81, 1962. b) Rajaram, C. V.; Hudson, S.; Chien, L. Chem. Mater. 1995, 7, 2300.

16. Tseng, M.; Meng, C.; Tang, S.; Kwok, H. U.S. Pat. 62/603,602 (2017).

17. Jeon, B.-G.; Choi, T.-H.; Do, S.-M.; Woo, J.-H.; Yoon, T.H. IEEE Trans. Electron Dev. 2018, 1, 4387.

18. Sun, H.; Xie, Z.; Ju, C.; Hu, X.; Yuan, D.; Zhao, W.; Shui, L.; Zhou, G. Polymers. 2019, 11, 694.

19. Dierking, I. Polym. Chem. 2010, 1, 1153.

20. Huang, C.-Y.; Chih, Y.; Ke, S. Appl. Phys. B. 2007, 86, 123.

21. Ma, R.-Q.; Yang, D.-K. Phys. Rev. E. 2000, 61, 1567. Ma, J.; Shi, L.; Yang, D.-K. Appl. Phys. Express. 2010, 3, 021702 .

22. Dierking, I.; Kosbar, L.; Lowe, A.; Held, G. Liq. Cryst. 1998, 24, 397.

23. a) Dierking, I.; Kosbar, L.; Afzali-Ardakani, A.; Lowe, A.; Held, G. J. Appl. Phys. 1997, 81, 3007. b) Hu, X.; Zeng, W.; Yang, W.; Xiao, L.; De Haan, L. T.; Zhao, W.; Li, N.; Shui, L.; Zhou, G. Liq. Cryst. 2019, 46, 185. 